Bangladesh J. Plant Taxon. 28(1): 233-240, 2021 (June)

(C) 2021 Bangladesh Association of Plant Taxonomists

https://doi.org/10.3329/bjpt.v28i1.54219

\title{
TWO WAY INDICATOR SPECIES ANALYSIS OF WEED SPECIES OF POTATO AND WHEAT CROP FIELDS OF SHARQPUR TEHSIL, PAKISTAN
}

\author{
Sohaib Muhammad*, Sarah Maryam Malik, Zaheer-Ud-Din Khan, Muhammad \\ Tayyab, Andleeb Anwar Sardar, Muhammad Zahid and Nimra Akram
}

Department of Botany, GC University, Lahore, Pakistan (54000)

Keywords: TWINSPAN; Weeds; Potato; Wheat; Crop Fields; Pakistan.

\begin{abstract}
This study was carried out to determine the distribution of the weeds in two important cash crops of Pakistan along with their distribution pattern in research area. Total of 56 weed species was recorded belonging to 23 plant families by the quadrat method with random sampling in wheat and potato fields of seven different villages from Tehsil Sharqpur Sharif, Punjab, Pakistan. A multivariate technique, Two Way Indicator Species Analysis (TWINSPAN), using PC-ORD (Version-6.22) classified the weeds into groups and associations. The dominant weed communities were Cichorium-EuphorbiaCyperus community, Chenopodium-Digera-Fumaria weed community, PoaChenopodium-Coronopus weed community, Parthenium-Euphorbia-Veronica weed community, Euphorbia-Achyranthes-Brassica community and Setaria-PolypogonSolanum community. Phytodiversity of weeds found in this study, remarkably indicated the variable distribution pattern of weeds in both the crop fields. Moreover, communities of weeds emerged can be helpful in better planning of the weed management in crop fields.
\end{abstract}

\section{Introduction}

Agriculture in Pakistan is renowned across the world for the production of potato (Solanum tubersum L.) and wheat (Triticum aestivum L.), but the presence of weeds in these crop fields is infesting the problems of crop growth and yield, as the weeds are competing with the crop plants for their nutrients, food, sun light etc. Apart from their negative impact on yield of the crop, there are certain weed species which has their ethnomedicinal values and due to irregular agriculture practices, these species also facing a threat for their lives. The composition and richness of the weed communities present along the edges and within the crop fields reduces the quality and quantity of the crops (Muhammad et al., 2009; Khaliq et al., 2013).

Identification and distribution pattern of these weed species has its integral importance in crop management and as well as in their economic utility. Several scientists worked on the distribution of the weed communities in various crops in various parts of the world, such as Nikolic et al. (2013) analyzed the weed flora of Potato, in which of thirty nine (39) plant weeds species were found and classified into sixteen (16) families and thirty two (32) genus. Khobragade and Sathawane (2014) surveyed weeds of wheat crop of Bhandara district (M.S.), India. They reported, seventy six (76) weed species which belonged to twenty four (24) dicotyledonous and three (3) monocotyledonous families. Muhammad et al. (2015) find out distribution pattern of weeds of some vegetable crops in Tehsil Gojra, Pakistan. Forty (40) weeds species were found to be distributed among seventeen different families. Ullah et al. (2016) surveyed the Lower Dir, Pakistan. They reported forty (40) weed species growing in the wheat crop, belonged to twenty one (21) different families. They evaluated the plants on the basis of their medicinal values and ecological importance.

*Corresponding author. email: dr.sohaibmuhammad@gcu.edu.pk 
Navagana et al. (2017) surveyed the cotton crops of Visakhapatnam District and performed the quantitative analysis on the weeds in the fields. They explored the floristic composition of weed and determine the frequency, density and cover of 55 different weed species of twenty one different plant families. Begum and Ahmad (2018) studied the weeds of Wheat at Kohat, Khyber Pakhtunkhwa. They studied the leaf and life form of the weeds. They collected 60 weed species belonging to 23 families. Ali et al. (2019) determined phytoecological aspects of weed flora of wheat in Tehsil Charsada (KPK), Pakistan. They reported 32 weed species belonged to 18 different plant families. From these weed species five dominant weed communities were emerged through their ecological ordination analysis. These weed communities were Coronopus-PoaAnagallis, Veronica-Coronopus-Melilotus, Anagallis-Euphorbia-Veronica, Melilotus-CoronopusPoa and Polygonum-Ranunculus-Veronica. Usman et al. (2020) reported 36 weed species from wheat crop fields of District Khanewal (Punjab), Pakistan, distributed among 15 plant families among which family poaceae was found to be the dominant one with ten different grass species. Considering the noxious behavior, their competitive abilities with crop and some useful aspect with respect to their medicinal values, the present project was designed to assess the ecological distribution of weed species of the wheat and potato crop fields of Tehsil Sharaqpur (Punjab) Pakistan.

\section{Materials and Methods}

The research work was carried out in some selected potato and wheat crop fields of Tehsil Sharqpur, Pakistan by selecting seven different villages of the Tehsil in which both of these crops were grown. Further, in these villages, three fields of almost equal size were selected for both the crops.

\section{Sampling Technique}

After selecting the crop fields' random sampling for the collection of the weeds was performed and ecological data was collected. For sampling the quadrat method was used and the size of the quadrat was $1 \mathrm{~m}^{2}$ after Clements (1905).

\section{Floristic Composition}

After taking quadrats in respective fields of both the crops, different weeds were collected, preserved, and identified with the help of available literature present in Flora of Pakistan (Nasir and Ali, 1970-89; Ali and Nasir, 1990-92; Ali and Qaiser, 1992-2007).

\section{Ecological Data}

Ecological data was collected by recording \% frequency, density and \% cover was recorded as the basic parameters following McIntosh (1962), Curtis and McIntosh (1950) and Daubenmire (1959), respectively. These three basic parameters lead the basis for more precise ecological calculation in terms of relative frequency, density and cover (Muller-Dombois and Ellenberg, 1974). From these three relative values, the Importance Value (IV) was calculated (Curtis, 1959) which provided the basis for more precise and accurate calculations of the ecological data as Importance Value Index (IVI) (Risser and Rice, 1971).

Two Way Indicator Species Analysis (TWINSPAN)

For determination of weed communities of both the crops, a multivariate technique was used in which the weed communities were emerged on the basis of \% cover by using the PC-ORD (Version-6.22; McCune and Mefford, 2010). 


\section{Results and Discussion}

Total fifty four weed species were reported belonging to twenty one different families in potato and wheat as shown in Table 1. Ecological communities of potato and wheat crop of Tehsil Sharaqpur are divided into two major groups, i.e. GA (Group-A) and GB (Group-B). These main groups are further divided into two subgroups, viz. Sub-Group1 (SG1) and Sub-Group2 (SG2). These Sub-Groups were further divided into Associations, i.e. Association 1 (A1) and Association 2 (A2). These groups, sub-groups and associations were developed on the basis of \% cover of individual weed species in respective crop fields.

Table 1. Ecological Characteristics of Weed Species of Potato and Wheat Crop Fields of Tehsil Sharqpur (Punjab) Pakistan.

\begin{tabular}{|c|c|c|c|c|c|c|c|}
\hline $\begin{array}{l}\text { Sl. } \\
\text { No. }\end{array}$ & Fami & Weed species & $\begin{array}{l}\text { Weed species } \\
\text { abbreviations }\end{array}$ & R.F. & R.D. & R.C. & IVI \\
\hline \multirow[t]{3}{*}{1.} & Amaranthaceae & 1. Amaranthus viridis $\mathrm{L}$. & Ama-vir & 1.32 & 1.17 & 1.43 & 1.30 \\
\hline & & 2. Achyranthes aspera $\mathrm{L}$. & Acy-asp & 3.06 & 1.84 & 2.78 & 2.56 \\
\hline & & 3. Digera muricata (L.) Mart. & Dig-mur & 6.23 & 3.88 & 5.60 & 5.23 \\
\hline \multirow[t]{7}{*}{2.} & Asteraceae & 1. Carthamus oxyacantha M. Bieb. & Car-oxy & 0.19 & 0.7 & 0.79 & 0.56 \\
\hline & & 2. Cichorium intybus L. & Cic-int & 5.51 & 2.89 & 5.35 & 4.58 \\
\hline & & 3. Cirsium arvense (L.) Scop. & Cir-arv & 1.36 & 0.86 & 0.95 & 1.05 \\
\hline & & 4. Conyza ambigua DC. & Con-amb & 1.17 & 0.73 & 0.81 & 0.90 \\
\hline & & 5. Eclipta alba (L.) Hassk. & Ecl-alb & 1.07 & 0.64 & 0.78 & 0.83 \\
\hline & & 6. Parthenium hysterophorus L. & Par-hys & 4.39 & 4.39 & 6.24 & 5.00 \\
\hline & & 7. Sonchus asper (L.) Hill & Son-asp & 2.96 & 1.21 & 3.31 & 2.49 \\
\hline \multirow[t]{4}{*}{3.} & Brassicaceae & 1. Brassica campestris L. & Bra-cam & 1.46 & 1.2 & 1.36 & 1.34 \\
\hline & & 2. Coronopus didymus (L.) Smith & Cor-did & 3.47 & 1.48 & 4.40 & 3.11 \\
\hline & & 3. Eruca sativa Mill. & Eru-sat & 1.27 & 0.81 & 0.72 & 0.93 \\
\hline & & 4. Sisymbrium viridis $\mathrm{L}$. & Sis-vir & 0.78 & 0.28 & 0.24 & 0.43 \\
\hline 4. & Cannabaceae & 1. Cannabis sativa $\mathrm{L}$. & Can-sat & 2.86 & 1.58 & 1.92 & 2.12 \\
\hline 5. & Caryophyllaceae & 1. Stellaria media (L.) Vill. & Ste-med & 1.94 & 1.49 & 1.94 & 1.79 \\
\hline \multirow[t]{2}{*}{6.} & Chenopodiaceae & 1. Chenopodium album L. & Che-alb & 5.42 & 5.56 & 6.40 & 5.79 \\
\hline & & 2. Chenopodium murale $\mathrm{L}$. & Che- mur & 5.01 & 3.65 & 5.26 & 4.64 \\
\hline 7. & Convolvulaceae & 1. Convolvulus arvensis $\mathrm{L}$. & Con-arv & 3.77 & 1.66 & 1.57 & 2.33 \\
\hline 8. & Cyperaceae & 1. Cyperus rotundus L. & Cyp-rot & 3.06 & 5.29 & 2.46 & 3.60 \\
\hline \multirow[t]{3}{*}{9.} & Euphorbiaceae & 1. Euphorbia helioscopia L. & Eup-hel & 4.19 & 1.38 & 6.14 & 3.90 \\
\hline & & 2. Euphorbia hirta L. & Eup-hir & 2.24 & 3.74 & 1.94 & 2.64 \\
\hline & & 3. Euphorbia prostrata Ait., Hort. & Eup-pro & 2.63 & 2.79 & 2.04 & 2.48 \\
\hline \multirow[t]{5}{*}{10.} & Fabaceae & 1. Lathyrus aphaca $\mathrm{L}$. & Lat-aph & 1.73 & 1.68 & 1.21 & 1.54 \\
\hline & & 2. Medicago denticulata Willd. & Med-den & 1.63 & 0.60 & 1.24 & 1.15 \\
\hline & & 3. Melilotus indica (L.) All. & Mel-ind & 2.45 & 1.41 & 1.73 & 1.86 \\
\hline & & 4. Melilotus sativa Mill. & Mel-sat & 0.71 & 0.19 & 0.32 & 0.40 \\
\hline & & 5. Vicia sativa $\mathrm{L}$. & Vic-sat & 2.44 & 1.12 & 2.2 & 1.92 \\
\hline 11. & Fumariaceae & $\begin{array}{l}\text { 1. Fumaria indica (Hausskn.) } \\
\text { Pugsley }\end{array}$ & Fum-ind & 5.52 & 7.22 & 7.54 & 6.76 \\
\hline 12. & Linaceae & 1. Linum usitatissimum L. & Lin-usi & 0.39 & 2.64 & 0.16 & 1.06 \\
\hline 13. & Malvaceae & 1. Malva neglecta $\mathrm{L}$. & Mal-neg & 3.68 & 2.85 & 1.78 & 2.77 \\
\hline
\end{tabular}


Table 1 contd.

\begin{tabular}{|c|c|c|c|c|c|c|c|}
\hline $\begin{array}{l}\text { Sl. } \\
\text { No. }\end{array}$ & Families & Weed species & $\begin{array}{l}\text { Weed species } \\
\text { abbreviations }\end{array}$ & R.F. & R.D. & R.C. & IVI \\
\hline 14. & Oxalidaceae & 1. Oxalis corniculata $\mathrm{L}$. & Oxa-cor & 0.40 & 0.22 & 0.28 & 0.3 \\
\hline 15. & Plantaginaceae & 1.Veronica agrestis $\mathrm{L}$. & Ver-agr & 1.84 & 1.40 & 0.95 & 1.39 \\
\hline \multirow[t]{14}{*}{16.} & Poaceae & 1. Avena fatua $\mathrm{L}$. & Ave-fet & 0.20 & 0.18 & 0.22 & 0.2 \\
\hline & & 2. Avena sativa $\mathrm{L}$. & Ave-sat & 1.22 & 0.39 & 0.55 & 0.72 \\
\hline & & $\begin{array}{l}\text { 3. Brachiaria reptans (L.) Gardner } \\
\text { \& Hubb. }\end{array}$ & Bra-rep & 0.58 & 3 & 0.55 & 1.37 \\
\hline & & 4. Bromus japonicas Thunb. & Bro-jap & 1.53 & 0.79 & 0.66 & 0.99 \\
\hline & & 5. Cynodon dactylon (L.) Pers. & Cyn-dac & 1.22 & 1.47 & 0.84 & 1.17 \\
\hline & & $\begin{array}{l}\text { 6. Dactyloctenium aegyptium (L.) } \\
\text { Willd. }\end{array}$ & Dac-aeg & 1.46 & 0.36 & 0.99 & 0.93 \\
\hline & & 7. Digitaria filiformis (L.) Koeler. & Dig-fil & 1.22 & 1.23 & 0.76 & 1.07 \\
\hline & & 8. Eleusine indica (L.) Gaertn. & Ele-ind & 0.78 & 0.06 & 0.39 & 0.41 \\
\hline & & 9. Eragrostis tenella (L.) P. Beauv. & Era-ten & 0.48 & 3.16 & 0.26 & 1.3 \\
\hline & & 10. Paspalum distichum L. & Pas-dis & 0.19 & 1.2 & 0.06 & 0.48 \\
\hline & & 11. Phalaris minor Retz. & Pha-min & 3.61 & 7.27 & 2.71 & 4.53 \\
\hline & & 12. Роа аппиа $\mathrm{L}$. & Poa-ann & 4.70 & 5.35 & 5.99 & 5.34 \\
\hline & & 13. Polypogonum aritimus Willd. & Pol-mar & 4.67 & 6.38 & 4.64 & 5.23 \\
\hline & & $\begin{array}{l}\text { 14. Setaria verticillata (L.) P. } \\
\text { Beauv. }\end{array}$ & Set-ver & 4.60 & 9.20 & 6.02 & 6.60 \\
\hline \multirow[t]{2}{*}{17.} & Polygonaceae & 1. Polygonum plebejum R. Br. & Pol-ple & 0.97 & 1.28 & 0.73 & 0.99 \\
\hline & & 2. Rumex dentatus L. & Rum-den & 1.73 & 0.65 & 2.21 & 1.53 \\
\hline 18. & Primulaceae & 1. Anagallis arvensis L. & Ana-arv & 3.27 & 4.55 & 1.04 & 2.95 \\
\hline 19. & Ranunculaceae & 1. Ranunculus muricatus L. & Ran-mur & 2.93 & 1.05 & 2.31 & 2.09 \\
\hline 20. & Solanaceae & 1.Solanum nigrum L. & Sol-nig & 3.27 & 2.57 & 3.86 & 3.23 \\
\hline \multirow[t]{2}{*}{21.} & Scorphulariaceae & $\begin{array}{l}\text { 1. Mazus pumilus (Burm.f.) } \\
\text { Steenis }\end{array}$ & Maz-pum & 1.07 & 1.83 & 1.13 & 1.34 \\
\hline & & 1. Verbascum thapsus L. & Ver-tha & 1.32 & 1.69 & 2.24 & 1.75 \\
\hline 22. & Verbenaceae & 1. Phyla nodiflora (L.) Greene. & Phy-nod & 1.17 & 1.83 & 2.33 & 1.77 \\
\hline 23. & Zygophyllaceae & 1. Tribulus terrestris $\mathrm{L}$. & Tri-ter & 0.48 & 0.19 & 0.2 & 0.29 \\
\hline
\end{tabular}

Plant Group A:

Group A was further divided into the two sub-groups (SGs) i.e. SG1 and SG2. The Sub Group 1 (SG1) is represented by three weed species i.e. Vicia sativa, Ranunculus muricatus and Phalaris minor having Importance Value Index (IVI) as 1.92, 2.09 \& 4.53, respectively. Presence of these weed species with comparatively high amounts of IVI values confirms the findings of Jan et al. (2012). The Sub Group 2 (SG2) was comparatively a large group and on the basis of association of weeds, it was further divided by two associations i.e. Association1 (A1) and Association2 (A2) as shown in Figure 1.

A1 consisted of Cichorium intybus, Cyperus rotundus, Euphorbia helioscopia, Malva neglecta and Cynodon dactylon having IVI as 4.58, 3.60, 3.90, $2.77 \& 1.17$, respectively. Out of these five species, three weeds were found dominant in this association with respect to their IVI values. These species were $C$. intybus, E. helioscopia and $C$. rotundus and it can be represented as Cichorium-Euphorbia-Cyperus weed community as shown in Figure 1. The prevalence such 
dominant weed species like $C$. rotundus, E. helioscopia and $C$. dactylon was confirmed by the findings of the Hanif et al. (2004) and Hussain et al. (2004).

Furthermore, in Association A2, total eight weed species were found i.e. Digera muricata having IVI Value 5.23, followed by Cannabis sativa with 2.12 IVI value. Remaining weed species were Sonchus asper (2.49), Digitaria filiformis (1.07), Chenopodium album (5.79),

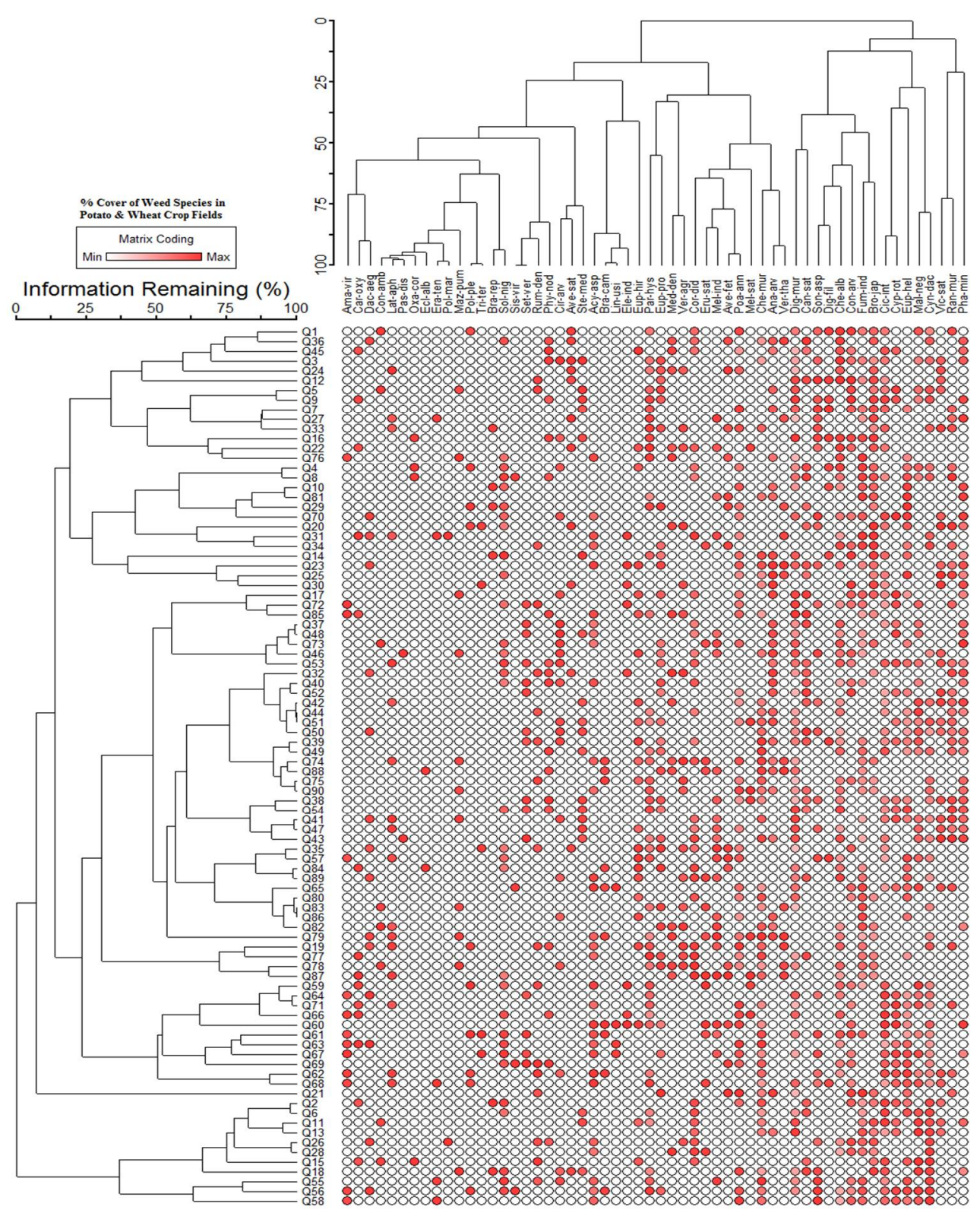

Fig. 1. Ecological Pattern of Weed Communities of Potato and Wheat crop fields of Tehsil Sharqpur (Punjab) Pakistan through TWINSPAN. 
Convolvulus arvensis (2.33), Fumaria indica (6.76) and Bromus japonicus with 0.99 IVI shown in Table1. In this association, Chenopodium-Digera-Fumaria was the dominant weed species community with highest IVI Values as shown in Table 1. In this weed community with its allied species it was observed that it is the most widespread weed species group having $C$. album, $C$. arvensis, $F$. indica which defines the findings of Khan et al. (2019).

Plant Group B:

Group B was further divided into subgroups (SGs), i.e. SG1 and SG2. The Sub Group1 (SG1) was represented by two associations i.e. Association1 (A1) and Association2 (A2). A1 association consisted of nine weed species i.e. Coronopus didymus, Eruca sativa, Melilotus indica, Avena fatua, Poa апnиa, Melilotus sativa, Chenopodium murale, Anagallisarvensis and Verbascum thapsus with variable IVI values. The dominant weed species were Poaannua, Chenopodium murale and Coronopus didymus with 5.34, 4.64 and 3.11 IVI values respectively. On the basis of these dominant weed species Poa-Chenopodium-Coronopus community was found along with $E$. sativa, M. indica, A. fatua, M. sativa, A. arvensis and V. thapsus weeds having IVI values as 0.93, $1.86,0.2,0.40,2.95 \& 1.75$, respectively as shown in Table 1 . Emergence of this weed community with their dominant members was also represented in another study i.e. Ali et al. (2019) as two of this community members viz., Poa annua and Coronopus didymus were present.

A2 association consisted of four weed species, viz. Parthenium hysterophorus, Euphorbia prostrata, Medicago denticulata and Veronica agrestis having 5.00, 2.48, 1.15 and 1.39 IVI values, respectively, as shown in Table1. On the basis of their greater IVI Values PartheniumEuphorbia-Veronica was found as dominant weed species community. In this community, presence of the $P$. hysterophorus weed with such high IVI value indicated its potential as invader weed species and this could be the one reason that due to its potential to replace local flora, this community of weed had very few members as it confirms the findings of Jan et al. (2012) and Malik et al. (2012).

The Sub Group 2 was further divided into two associations. Association 1 (A1) composed of five weed species (Fig. 1), viz. Achyranthes aspera, Brassica campestris, Linum usitatissimum, Eleusine indica and Euporbia hirta having 2.56, 1.34, 1.06, 0.41 \& 2.64 IVI Values, respectively, and Euporbia-Achyranthes-Brassica were found as the dominant weed community (Table 1). This weed community can be considered as medicinally important as their medicinal utilization is confirmed by Ullah et al. (2015), but their competitive behavior with specific crop in terms of its yield and productivity cannot be ruled out.

Association 2 (A2) consisted of largest group of weeds with twenty two weed species, in which three weed species i.e. Setaria verticillata, Polypogonum aritimus and Solanum nigrum were found dominant with 6.60, 5.23 and 3.23 IVI values that formed the Setaria-PolypogonSolanum weed community. This weed community had associations with other species in this group. The associated weed species with this community was Amaranthus viridis, Carthamus oxyacantha, Dactyloctenium aegyptium, Conyza ambigua, Lathyrus aphaca, Paspalum distichum, Oxalis corniculata, Eclipta alba, Eragrostis tenella, Mazus pumilus, Polygonum plebejum, Tribulus terrestris, Brachiaria reptans, Sisymbrium viridis, Rumex dentatus, Phyla nodiflora, Cirsium arvense, Avena sativa and Stellaria media having importance value index (IVI) as 1.30, $0.56,0.93,0.90,1.54,0.48,0.30,0.83,1.30,1.34,0.99,0.29,1.37,0.43,1.53,1.77,1.05,0.72$ and 1.79 , respectively as shown in Table 1 . Presence of 22 weed species in this association described its diverse nature and wide distribution pattern and alliance abilities of these species with each other. Such association of weeds or plant species confirms the phytosociological/ ecological findings of this study in consistence with Hassan et al. (2010), Ghahremaninejad et al. (2012) and Hadi and Ibrar (2015). 
The results of present research work indicated that presence of 56 weed species distributed among 23 different plant families not only indicate the diverse nature of the weeds in the area but also the mode of their infestation and how vigorously these weeds are competing with the respective crops for the their yield in the area. Some of the taxa, apart from their noxious behavior, possess some medicinal values. The weed species having the medicinal value must be properly managed with existing cropping systems so that sustainable utilization of the plants can be carried out and conservation of the useful and ethnobotanically important plants can be possible, which can be a step forward in conservation of plant diversity along with the improvement of the crop yield.

\section{References}

Ali, F., Gul, H., Naveed, A., Muhammad, J.B. and Ataullah, J. 2019. Phytosociology and some ecological attributes of weed flora of wheat in Tehsil Charsadda Khyber Pakhtunkhwa,Pakistan. Pak. J. Weed Sci. Res., 25(2): 121-136.

Ali, S.I. and Nasir, Y.J. 1990-92. Flora of Pakistan. Nos. 191-193. Department of Botany, University of Karachi and National Herbarium, PARC, Islamabad.

Ali, S.I. and Qaiser, M. 1992-2007. Flora of Pakistan. Nos. 194-208. Department of Botany, University of Karachi and National Herbarium, PARC, Islamabad.

Begum, U. and Ahmad, U. 2018. Assessing biodiversity and ecological attributes of wheat crop weeds in Kohat, Pakistan. Pak. J. Weed Sci. Res. 24(1): 37-51.

Clements, F.E. 1905. Research Methods in Ecology. The University Publishing Company, Lincoln, Nebraska, USA.

Curtis, J.T. 1959. The vegetation of Wisconsin: An ordination of plant communities. Univ. of Wisconsin Press, Madison, $657 \mathrm{pp}$.

Curtis, J.T. and McIntosh, R.P. 1950. The interrelation of certain analytic and synthetic phytosociological characters. Ecology 31:434-455.

Daubenmire, R. 1959. A canopy coverage method of vegetational analysis. Northwest Science 33: 43-64.

Ghahremaninejad, F., Shabkhiz, R. and Fereidounfar, S. 2012. Weed diversity in wheat fields of upper Indus plains in Punjab, Pakistan. Pak. J. Weed Sci. Res. 18(3): 337-355.

Hadi, F. and Ibrar, M. 2015. Ecology of weeds in wheat crops of Kalash valley, District Chitral, Hindukush Range, Pakistan. Pak. J. Weed Sci. Res. 21(3): 425-433.

Hanif, Z., Khan, S.A. Marwat, K.B., Khan, I.A. and Ullah, I. 2004. Important weeds of Wheat crop of malakandher farm, NWFP agriculture university, Peshawar. Pak. J. Weed Sci. Res. 10(3-4): 109-112.

Hassan, G., Khan, I., Khan, M.Z., Shah, N.H., Khan, M. and Liaqatullah, M. 2010. Weed flora of chickpea in district LakkiMarwat, NWFP. Pak. Sarhad J. Agric. 26(1): 79-86.

Hussain, F., Murad, A. and Durrani, M. J. 2004. Weeds communities in the wheat fields of Mastuj, district Chitral, Pakistan. Pak. J. Weed Sci. Res. 10(3-4):101-108.

Jan, U.H., Jan, A. and Shinwari, Z.K. 2012. Distribution of weeds in wheat fields of district Bannu, Khyber Pakhtunkhwa Pakistan. Pak. J. Weed Sci. Res. 18(3): 393-411.

Khaliq, A., Gondal, M. R. Matloob, A., Ehsan U., Hussain, S. and Murtaza, G. 2013. Chemical weed control in wheat under different rice residue management options. Pak. J. Weed Sci. Res. 19(1): 1-4.

Khan, M.N., Hadi, F., Bibi, M., Khan, N. and Shah, S.M. 2019. Utilitarian aspects of weeds of wheat fields in Charbagh valley district Swat Pakistan. Pak. J. Weed Sci. Res. 25(1):37-48.

Khobragade, D.P. and Sathawane, K.N. 2014. Weed diversity in Rabi wheat crop of Bhandara District (MS), India. Int. J. of Life Sciences A2: 128-131.

Malik, M.A., Khan, Z. and Khan, A.U. 2012. Weed diversity in wheat fields of upper Indus plains in Punjab, Pakistan. Pak. J. Weed Sci. Res. 18(3): 413-421. 
McCune, B. and Mefford, M.J. 2010. PC-ORD: Multivariate Analysis of Ecological Data. Version 6.22. MjM Software Design, Gleneden Beach, Oregon, USA.

McIntosh, R.P. 1962. Raunkiaer's Law of frequency. Ecology 43(3): 533-535.

Muhammad, S., Khan, Z. and Cheema, T.A. 2009. Distribution of weeds in wheat, maize and potato fields of Tehsil Gojra, District Toba Tek Singh, Pakistan. Pak. J. Weed Sci. Res. 15(1): 91-105.

Muhammad, S., Shafeeq, A., Siddiqui, M.F., Khan, Z. and Butt, Z.A. 2015. Weed assemblages in four vegetable crops of Tehsil Gojra, District Toba Tek Singh, Pakistan. Int. J. Biol. Biotech. 12(2): 309-316.

Muller-Dombois, D. and Ellenberg, H. 1974. Aims and Methods of Vegetation Ecology. John Wiley \& Sons, 55 pp.

Nasir, E. and Ali, S.I. 1970-89. Flora of Pakistan. Nos. 1-190. National Herbarium, PARC, Islamabad and Department of Botany, University of Karachi, Pakistan.

Navagana, N., Rao, B.V. and Maradana, T.N. 2017. Phytosociological studies on the weed flora of District, Andhra Pradesh, India. International Journal of Current Research 9(1): 44583-44587.

Nikolic, L., Ilic, O., Dzigurski, D. and Masic, B.L. 2013. Analysis of weed flora in conventional and organic potato production. Biologica Nyssana 4(1-2): 9-14.

Risser, P.G. and Rice, E.L. 1971. Phytosociological analysis of Oklahoma upland forest species. Ecology 49: 1006-1009.

Ullah, F., Ullah, A. and Sohail, A. 2016. Medicinal and ecological diversity of weeds in wheat crop at lower Dir, Pakistan. Pak. J. Weed Sci. Res. 22(4): 627-637.

Ullah, F., Ullah, A., Sohail, A. and Khan, R. 2015. Diversity, distribution and ecological importance of weeds in the maize crop at Maidan valley, Dir (1), Khyber Pakhtunkhwa, Pakistan. Pak. J. Weed Sci. Res. 21(4): 543-553.

Usman, M., Murtaza, G., Ditta, A., Bakht, T., Asif, M., Nadir, M. and Nawaz, S. 2020. Distribution pattern of weeds in wheat crop grown in District Khanewal, Punjab, Pakistan. Pak. J. Weed Sci. Res. 26(1): 47-59 